\title{
"Russenlager" and forced labour. Soviet prisoners of war in Bremen - "home" as a reference for historical memory Creating an exhibition on a voluntary basis: a case study
}

\author{
Kerstin True-Biletski*, Petra Redert**
}

\begin{abstract}
This article focuses on emotional approaches within the framework of the exhibition "Russenlager" and Forced Labour in Bremen. Having traced local events and circumstances related to general historical topics, we expose on 14 displays a network of camps of Soviet POWs ("Russenlager"), work commandos, places of labour and the profiting companies in Bremen. Accordingly, 'home' is the emotional core, combined with a face-to-face approach presenting individual Soviet POWs, depicted on facsimile registration cards, issued by the Wehrmacht, which we use as guides through the exhibition. Another biographical approach extends into the present, involving the contact with a relative of a Soviet POW, who was forced to work in Bremen until he perished.
\end{abstract}

Key words: Soviet POW, forced labour, collective memory, home, emotional approach.

\section{Introduction}

How can we examine and present in a historical exhibition a subject - "Russenlager" and forced labour. Soviet prisoners of war in Bremen - that belongs to dark chapters in the German collective memory, to the long-time denied and covered-up crimes of the Third Reich? Today the silence about the Nazi crimes is broken; however, they were to such an extent gargantuan that there still remain blank spots in public awareness. Crimes against Soviet Prisoners of War (POW), who are sometimes called 'forgotten victims', are among them.70 years after the end of World War II we are not the first ones who have engaged in the issue of Soviet POW, but stand on the shoulders of historians and exhibition makers in public institutions or non-profit organizations and civil society initiatives in this field who have come before us. In autumn 2014, a non-profit association presented its touring exhibition "Russenlager" and forced labour. Pictures and memories of Soviet prisoners of war in the House of Science in Bremen in cooperation with a local initiative. As members of this initiative, we developed and showed the local complementary exhibition "Russenlager" and forced Labour. Soviet prisoners of war in Bremen.

\section{Historical background}

On 22 June 1941 the German invasion of the Soviet Union started. During the following German war against the Soviet Union about 5.7 million Soviet POW were taken into German captivity. More than 3 million of these died, mostly of exhaustion and tuberculosis because of their prison conditions: lack of food, hard work, lack of hygiene, poor clothing and shelter, violence, humiliation and despair. More than half of the Soviet POW died. The tremendousness of these numbers becomes more apparent when we notice that, out of 232,000 English and American POW in German camps during World War II, 8,348, or 3.5 per cent, died (Streit 2012: $60)$. In view of the fact that the Soviet Government had not signed the Convention relative to the Treatment of Prisoners of War (Geneva 1929), the German Wehrmacht felt free to treat Soviet POW purposely and methodically much worse than POW of other nations (except only for the Italian Military Internees). As enemies classified as Slavic subhumans, 'slawische Untermenschen', according to Nazi racial ideological terms, Soviet POW in all respects were 
placed at the bottom of the scale. During the planning of the war against the Soviet Union, the Wehrmacht leadership had already accepted Hitler's ideological war aims.

Only fifty years later, 1995-1999, the hitherto widespread image of the 'unblemished Wehrmacht' was shattered by the touring exhibition War of Annihiliation - Crimes of the Wehrmacht 1941-1944 made by the Hamburg Institute for Social Research. Enormous public interest and protests, and finally the detonation of a $4 \mathrm{~kg}$ bomb, proved its controversial nature. The exhibition became a political issue. At the height of the controversy new findings concerning a few photographs were used to attack the credibility of the exhibition. The exhibition was withdrawn, and a commission of historians confirmed its main theses:

It is indisputable that, in the Soviet Union, the Wehrmacht not only 'entangled' itself in genocide perpetrated against the Jewish population, in crimes perpetrated against Soviet POWs, and in the fight against the civilian population, but in fact participated in these crimes, playing at times a supporting, at times a leading role. These were not isolated cases of 'abuse' or 'excesses'; they were activities based on decisions reached by top-level military leaders or troop leaders on or behind the front lines (Hamburg Institute of Social Research 2004: 36)1.

Acompletely revised exhibition was shown from 2001-2004. The discussions on the controversy are documented and commented on in literature (Hamburger Institut für Sozialforschung 1996 and 2002; Heer 2014).For decades, German society hardly recognized the suffering of Soviet POW in general and as forced labourers in particular. From autumn 1941 onwards Soviet POW where incorporated in the German system of forced labour, which the Nazi regime had established already before World War II in the Third Reich and which took on gigantic dimensions during the war in the German Reich and the occupied countries. In Hamburg in November 2015, the touring exhibition Forced labour. The Germans, the forced labourers and the war illustrates this:

More than 20 million men, women and children from almost all countries in Europe were deported to National Socialist Germany as 'foreign workers', prisoners of war and concentration camp inmates, or they worked as forced labourers in German-occupied territory. [...] Forced labour was no secret; it was a crime largely open to public view².

Despite that, for fifty years, exploitation, mistreatment and racist repression of millions of people in the system of forced labour were hardly a public issue in Germany. The survivors of forced labour remained widely excluded from German compensation legislation and jurisdiction. Several class actions of US victims since 1997 claiming compensation for their slave and forced labour made the breakthrough, and led to tough bargaining. The German Government rejected any legal right to compensation, but offered a much less expensive humanitarian financial aid at its own discretion. In an out-of-court settlement the sum of ten billion DM shared by the government and leading German companies was agreed upon. In 2000 the foundation EVZ Erinnerung, Verantwortung, Zukunft (Remembrance, Responsibility, Future) was established for disbursing these 'individual humanitarian payments' to former slave and forced labourers and other victims of National Socialism (NS), excluding the POW. War imprisonment was classified as a general fate of war, and accordingly, should not serve as a basis for any individual compensation payments. Individual payments served to prevent the creation of 'vast precedents in reparation law' (Hense 2008: 150). The symbolic benefit for German policy and economy is expressed e.g. in the name of the foundation EVZ in the sense of coming to terms with the past, present moral integrity, and future human rights orientation (cf. Hense 2008: 268).

Compensation of Soviet (and other) POW had not just been forgotten but was deliberately prevented. This gap was filled by civil commitment; for example, the non-profit association mentioned above collects donations for former Soviet POW and other survivors of NS crimes in successor states of the former Soviet Union who were not eligible for the EVZ individual lump-sum payments. Only recently, in May 2015, the German Parliament decided to allocate individual symbolic 'one-time payment to former Soviet prisoners of war in recognition of their treatment in German detention'3. 


\section{General conditions of the Bremen exhibition}

The project to present the association's exhibition "Russenlager" and forced labour. Pictures and memories of Soviet Prisoners of War in Bremen in 2014 aimed to inform the public about these historical facts and to support political demands for official payments to former Soviet POW. At the beginning of 2013, the local initiative was extended from some few persons to about 14, including us, and began to organize a programme of expert lectures, guided tours at memorial places in Bremen, and a play reading on the given and closely connected subjects. We are the authors of the complementing local exhibition "Russenlager" and forced labour Soviet Prisoners of war in Bremen.

\section{Personal motivation and main idea of the conception}

Apart from the chance to use our skills as cultural historians in practice, our motivation to engage ourselves in the exhibition project was the local connection to the subject of both of us. Indeed, 'home' had been our personal starting point for doing research on the subject of Soviet POW a long time before the exhibition project came up. A camp for dying Soviet POW was located at Kerstin True-Biletski's native place, the village of Rohrsen, and a so-called "Russenlager", one of several camps for different groups of forced labourers, in the surroundings of Petra Redert's home in the Bremen city district Neustadt. Stunned by the synchronicity of present everyday life and quite a different, weird everyday life in the past - at least we are aware that the past never passes - our idea was to reveal the disconcerting narrative lying beneath the everyday surface of the cityscape. In doing so we intended to face the people in Bremen with the subject of forced labour of Soviet POW, which, for the time being, is still a not well-known part of history. Consistently, in order to catch especially local people's interest, we chose the local connection of our subject as the main trigger.

Salomon Korn, vice chairman of the Central Council of Jews in Germany put it this way:

The fire of authentic memory will extinguish bit by bit. [...] After the passing of contemporary witnesses the task of future remembrance work will be to transform the available only mediate memory into communicable memory. [...] As soon as history is bound to a place, particularly to a place nearby, it loses its often inherent aura of abstractness and thereby, in the literal sense of the word, crowds us. Sidestepping this confrontation with history tied to own everyday life is not possible just like that ${ }^{4}$.

Thus the act of remembering can make us aware of a refracted image of home (Heimat). The German word Heimat defies adequate translation. 'Issues of memory and space are intrinsic to the very notion of Heimat. [...] The notion of Heimat carries with it a long history of usages and appropriations that are tied specifically to German national and cultural history' (Eigler and Kugele 2012: 1).

During the Nazi regime the term Heimat was utilized to back the ideology of Blood and Soil, "Volksgemeinschaft" (people's community) etc. 'A retrospect of the 20th century shows that Heimat is not a harmless word. In the last century it belonged to the ideologically and politically most embattled terms and had a polarizing effect in literature and policy'5 (Hüppauf 2007: 109). After being quasi-rehabilitated decades later the term is still fraught with ambiguity and bulkiness. In any case it is emotionally laden. 'Central to both traditional and revisited conceptions of Heimat are the components of longing and belonging' (Wickham 1999: 8). Being aware of the immanent ambiguity of the term Heimat, this 'generator of associations' (Gebhard et al. 2007: 9), we refer to it mainly as a chronotope connoted positively with emotions like feeling at home, feeling confident in one's familiar surroundings, one's neighbourhood. The following definition comes quite close:

Heimat as a world nearby, comprehensible and transparent, a frame, where expectations of behaviour are becoming stable, where reasonable, predictable acting is possible - thus, Heimat as a contrast to otherness and alienation, as a realm of acquirement, of active permeation, of reliability ${ }^{6}$ (Bausinger 1980: 20). 
Nevertheless, this peaceful notion is not complete without keeping in mind the monstrosities of history and the present.

\section{Research resources}

The most important foundations of our research were the results of a research project of the Stiftung niedersächsische Gedenkstätten ${ }^{7}$ (Foundation Lower Saxonian Memorial Sites) in Celle on the work deployment of Soviet POW within the Wehrmacht's camp system in the area of contemporary Lower Saxony. We tracked the Soviet POWs' traces first of all in archives in Bremen, especially in the Staatsarchiv Bremen. Furthermore, we were able to lean on various former research results on the local and general history of forced labour and captivity during World War II. Other sources were contemporary witnesses who came in touch with Soviet POW as children. An indispensable source was the Russian online database http://obd-memorial.ru 8. From summer 2013 onwards the search criterion 'place of death' allowed us to find about 550 personnel cards of Soviet POW who lost their lives in Bremen. These personnel cards can be considered the core of the exhibition. Several personnel cards of Soviet POW who had been forced to work in Bremen without evidence of their death we found at Baracke $27^{9}$, a memorial site in Schwanewede near Bremen.

\section{The exhibition - overview}

The results of our research on the fate of Soviet POW in Bremen we represented in 14 displays in the form of posters in $\mathrm{A} 0$ format, including a map of Bremen depicting more than 30 places where Soviet POW were forced to work or lie buried, and a construction plan for hitherto unknown barracks in the Northern area of Bremen, which we detected in a municipal archive. Besides the displays three-dimensional objects were exhibited. The Memorial Place Camp Sandbostel (Gedenkstätte Lager Sandbostel) ${ }^{10}$, located in Lower Saxony, supplied us with several exhibits as a loan, which were presented in a glass cabinet: metal lunch pails, carved by Soviet POW with initials and simple ornaments, pieces of handicraft like small woven baskets and original photographs taken by German soldiers of Soviet POW in the camp and on their way to it. Original official documents, provided by the State Archive of Bremen, were presented in two further glass cabinets.

\section{Visitors' expectations}

Visitors to an exhibition on a historical subject are provided with pre-existing individual memories and collective memories of their families, generation, ethnic group or nation. 'Collective memory' can be seen as a metaphor for the myths, traditions, customs, or heritages of the respective group representing its 'spirit' or 'psyche' (Gedi and Elam 1996: 30). Jan Assmann's concept of cultural memory - as a manifestation of collective memory - 'comprises that body of reusable texts, images, and rituals specific to each society in each epoch, whose "cultivation" serves to stabilize and convey that society's self-image' (Assmann, 1995: 132). Cultural memory is always linked with the present, it 'works by reconstructing, that is, it always relates its knowledge to an actual and contemporary situation' (Assmann, 1995: 130).

The divergence of cultural memory regarding NS, as passed on at school or through media, and individual and collective memory, as passed on in families (cf. Welzer et al. 2002: 11 ), and the natural death of contemporary witnesses, are challenging circumstances for the presentation of subjects related to the NS. 'The abstract memory, based on learned knowledge, needs new secondary forms of experience and sensual perception to be emotionally pervaded and individually acquired'11 (Assmann 2003: 136).

So, what do visitors expect? A comparison of more than 30 visitor polls at German documentary centres and memorial sites giving information on the victims of NS and furthermore SOZ / SBZ (Soviet occupation zone / Sowjetische Besatzungszone) and GDR made clear that, despite being mostly satisfied with their visit, the interviewees' focal points of criticism were a 'lack of vividness and authenticity', as well as a 'lack of information on the place or insufficient biographic details of captives or perpetrators'. Accordingly, the interviewees 
positively emphasized the presence of 'historic relics, photographs and palpable objects as well as information on genuine fates of captives [...]' (Pampel 2007: 104-5). Though an exhibition can only to a limited extent compete with the auratic impression of a memorial site, visitors would most likely attend it with very similar expectations, which are first of all vividness and authenticity. 'Relevant for individual knowledge transfer are not only knowledge transfer or remembrance of the victims, but the confirmation through on-site visits of the historic location as well as comprehension and visualization of the occurrence'12 (Pampel 2007: 113-4). This conclusion carries weight as well for an exhibition presenting original locations of camps and places of work commandos through present-day photographs, and showing individual photographs of Soviet POW and objects, produced and modified by the captives. The following recommendation comes quite close to our notion: 'Organizing the visit as an adventure means to enable holistic experience through heart, hand and mind, e.g. deeper understanding and graphic visions by vividness, empathy by biography-oriented configuration, auratic experience by authenticity [...] $]^{133}$ (Pampel 2007: 374).

\section{The exhibition - description of different ways to arouse visitors' interest and emotions}

Present-day photographs represent the places in Bremen where camps existed or POW were forced to work. Visitors may easily recognize these places, supported by the city map of Bremen. Laminated personnel cards serve as guides through the exhibition. The written interview transcripts of contemporary witnesses who describe their encounters with Soviet POW when they were children make the visitors participate in a vivid emotional narrative. Historical photographs and archive documents depicted on the displays illustrate the provided information on the historical context. This documentary material appeals to a cognitive perception and completes the emotional access in order to engage the visitors on different levels. The exposed carved lunch pails and handcrafted baskets guarantee authenticity and provide a basis for close apperception. Thus these objects, being metonymic with the Soviet POW, provide a sensual impression of authenticity which is an effective access path to evoke emotions.

\section{Entrance - facing the faces}

The two parts of the exhibition - the general part of the association and our Bremen part - were presented in two separate exhibition halls of the Haus der Wissenschaft (House of Science).

One common part, though, we exposed together in the hallway, which opens to visitors immediately after entering the building. Six vinyl displays, each of them depicting six personnel (registration) cards in A4 format of Soviet POW of work commandos deployed in Bremen were alternated with life-size portraits of survivors taken by a photographer some years ago for the association.

At this stage visitors are confronted with an impression of masses of prisoners of war in contrast to the few individual old men who had survived. A strange kind of encounter or dialogue takes place in a virtual spatiotemporal dimension, which is fraught with tension and sorrowful, melancholic emotion. The old men encounter their woeful past, the captured soldiers face their at that time potential future - staying alive and growing old, which remained unfulfilled, though, since most of the depicted POW died in Bremen. In retrospective, the survivors would most likely bemoan not only their own past as captives but bewail the fate of their contemporary comrades in arms, simultaneously being at ease or/and feeling guilty and uneasy because of their own survival. Thus or similar might be an imaginary visitor's contemplation on this imaginary intergenerational dialogue throughout space and time. Even more important, though, is the imaginary dialogue between the depicted POW and the visitors. The range of faces is meant to leave a deep impression. Masses of rather small-sized faces, oscillating between anonymization and - due to personal data exposed within a bureaucratic context - individualization, interact with the life-size informal portraits - all of them confronting the visitors, evoking compassion and shame.

One bigger than life-size photograph, depicting a survivor standing upright in his domicile and looking straight ahead to the incoming visitor, intensifies this first powerful emotional impact. 
After passing the hallway, visitors had the choice of starting with the touring exhibition providing a general overview or with the exhibition describing the situation in Bremen. We assume that local people would most probably start with the Bremen part, due to their inevitably emotional affinity to their home town. Hereinafter we refer only to the Bremen part of the exhibition.

\section{Personnel cards as guides through the exhibition}

A way to arouse visitors' curiosity is to invite them to actively participate in discovering the exhibition. Thus, 'cultural window-shopping' and 'active dozing', terms coined by Treinen, by 'receiving and maintaining permanent stimuli' (Treinen 1988: 33), with a low and cursory attention span, would be less tempting for the visitors, too.

A rack with laminated copies of several different personnel cards positioned directly at the end of the hallway at the starting point of the Bremen exhibition invited visitors to pick up a card and trace the various stations of an individual Soviet POW - from his arrival in the camp outside of Bremen through local work commandos up to the cemetery. Hereby the cards served as guides through the exhibition. Such a principle of biographical guidance is used e.g. at the Deutsches Auswandererhaus (German Emigration Center) Bremerhaven, a harbour town located about $70 \mathrm{~km}$ north of Bremen.
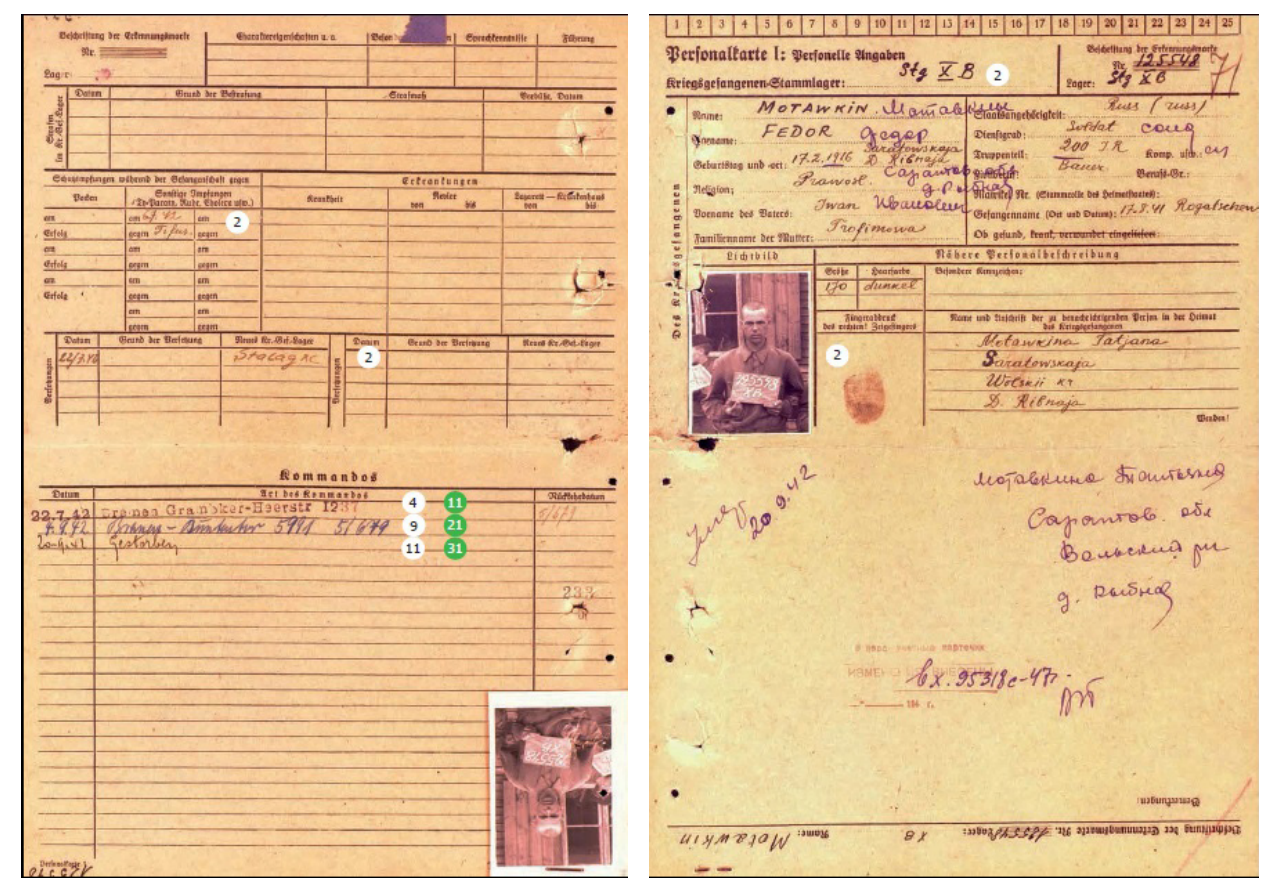

Image 1. Personnel card of Fedor Motavkin. Electronic Archive of the Dokumentationsstelle Dresden/Stiftung Sächsische Gedenkstätten, DB SowjKgf ID 692855

The numbers in white circles on the cards lead to the displays with corresponding numbers where visitors get information on the various life stations of 'their' Soviet POW. The numbers in green circles lead them to the locations of the work commandos and cemeteries on the Bremen map. Indications on the personnel cards are: responsible main camp, registration number, personal data, fingerprint, addresses of relatives, nationality (usually ethnicity was recorded), profession, date of capture, state of health, vaccinations, times of illness, work commandos, date of death or last whereabouts. About half of the personnel cards are provided with photographs. These officially taken photographs leave an ambiguous impression. The 
photograph of the usually shaved POW holding a plate with his registration number documents the situation of war imprisonment which is not controlled by the POW. As a Soviet captive he is especially vulnerable and exposed to the Wehrmacht, rather a number than an individual. On the other hand the Wehrmacht actually confirms the POW's individuality by registering and subsequently ensuring his organized deployment in the work commandos and furthermore ensures that at least his death will not be anonymous but documented. Through the registration the POW steps out of anonymity. Though, as we said above, many of the personnel cards had no photographs and the POW was identified with a fingerprint. For the exhibition we chose only personnel cards with photographs, because they give an immediate impression of the

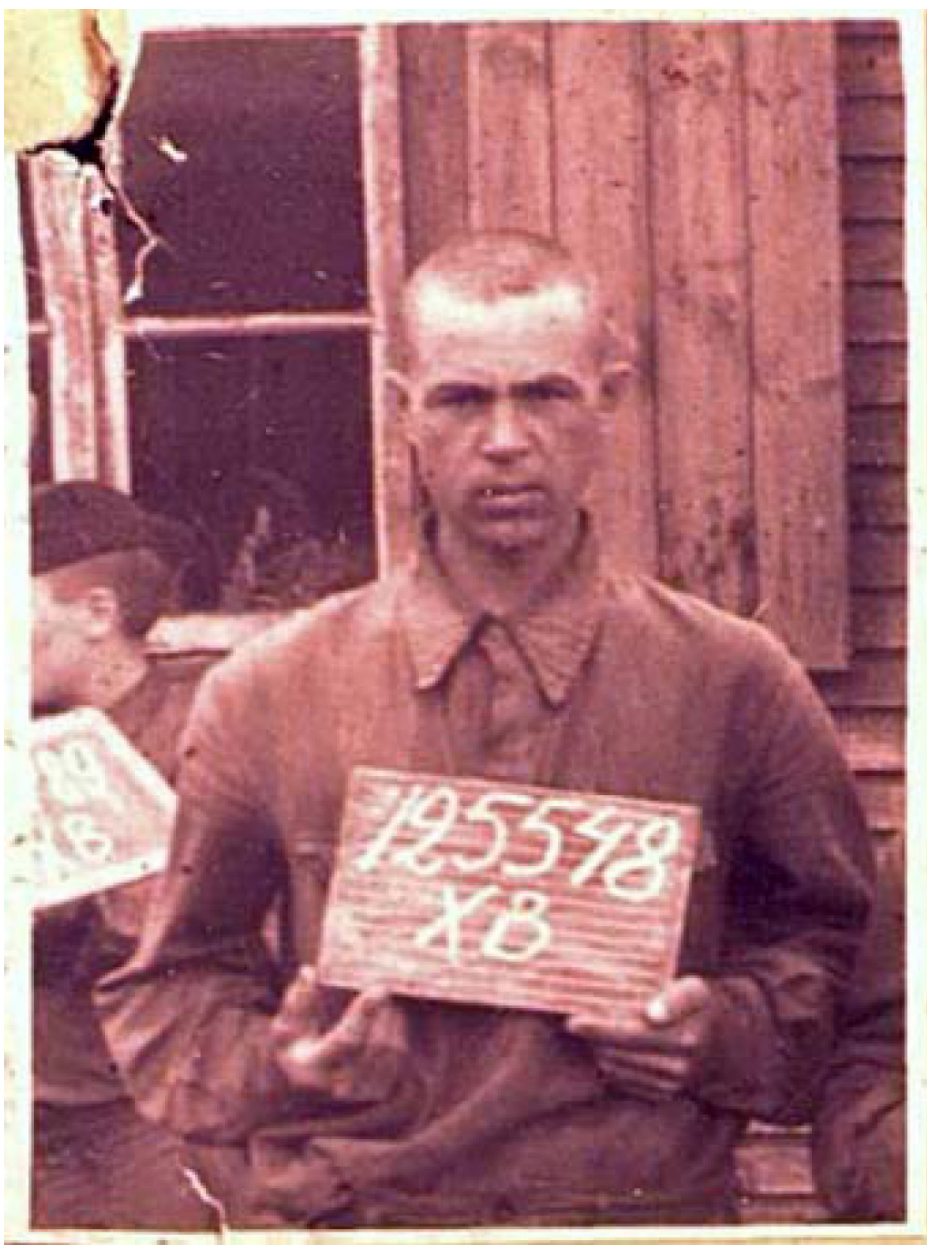

Image 2. Photograph of Fedor Motavkin: Electronic Archive of the Dokumentationsstelle Dresden/Stiftung Sächsische Gedenkstätten, DB SowjKgf ID 692855 individual.

Byholdingthecard in their hands and actively learning about these data the visitors experience a transformation - the POW is no longer part of the masses but turns into an individual whose biographic stations in Bremen the visitors have the chance to follow - a young soldier of 25 years, born in the province of Saratov on the Volga river, captured in Rogachev, Belarus, in August 1941, assigned to two work commandos, information on which is supplied on the corresponding displays. Fedor Motavkin survived not even five months in Bremen before he died. By taking the perspective of the victim, empathy and discomfort should be adequate emotional reactions of a Bremen citizen looking at the soldier, a step-by-step increasing familiarity with him might correspond with an increasing alienation from his or her own hometown.

Asimilaremotional strategy, evoking visitors' empathy by creating an encounter through portraits of others, is undertaken in an installation within Bujilaka gallery at the Melbourne Museum, albeit referring to Aborigines by partly using videotaped narration. 'Its power to arrest the visitor comes from three things - as you walk around it, you are eye to eye with someone you normally think of as very different from you. They look back at you, as if to question your colonial gaze but also to engage you in conversation.' (Whitcomb 2013: 264). Changing the perspective through 
empathy on this way of grief is a device to affect visitors emotionally. Especially through this change of perspectives, through the eyes of the POW, the visitor is challenged to query the familiar image of the seemingly stable hometown Bremen, which is now being seen in another light and reappraised. General historic facts which Germans learn about the NS at school, through mass media or at visits to memorial sites constitute the general historic educational background and thus the collective memory. Holding the personnel card in their hands, visitors discover our research results on Russenlager and forced labour in Bremen provided on the displays. The interaction of both cognitive and emotional approaches enables them to picture the POW's individual way through Bremen. Especially interesting for visitors were locations of importance for their own life, e.g. their neighbourhood or childhood memories ${ }^{14}$. Thus two individual lives out of the past and present cross in the visitors' imagination and effect a change of the own point of view, and a human relationship emerges. According to the report of one visitor, a feeling of responsibility ultimately occurred ${ }^{15}$.

\section{Before coming to Bremen. Disturbing photographs from the main camps and later transformation of horror into comic art}

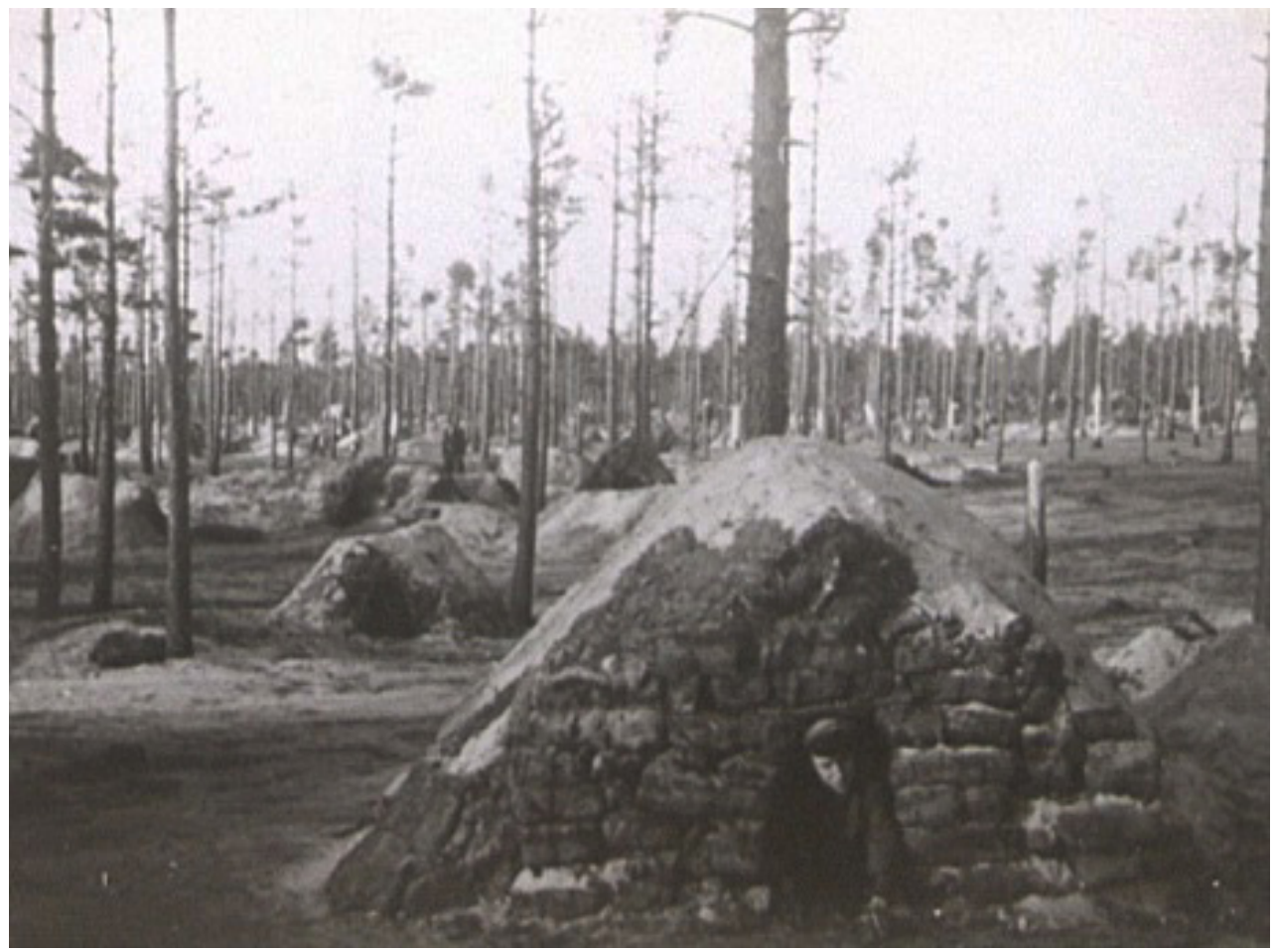

Image 3. Burrows in StaLag XD Wietzendorf, Staatsarchiv Hamburg, 213-12 NSG 4 Bd.7 Nr.17

Before being allocated to the various work commandos the captives were registered, medically examined, disinfected and vaccinated in the main camps. Bremen belonged to the Wehrkreis (military district) $\mathrm{X}$, three main camps were responsible for the allocation of work commandos to Bremen: StaLag (= Stammlager) XB Sandbostel, StaLag XC Nienburg (only organization and administration of labour deployment of POW) and StaLag XD (310) Wietzendorf (Russenlager, since 1943 central hospital for Soviet POW in Wehrkreis X).

On arrival the circumstances were disastrous, no shelter, malnutrition, the Soviet POW had no alternative but to dig burrows for shelter and even resort to eating tree bark in their desperation. The widespread deaths of Soviet POW in winter 1941/42 took place not only in 
the occupied countries, but also about $100 \mathrm{~km}$ from Bremen in camp XD (310) Wietzendorf, where up to March 1942 14,500 Soviet POW died. Three photographs, which we found in the catalogue of the revised exhibition Verbrechen der Wehrmacht. Dimensionen des Vernichtungskriegs 1941-1944 (Hamburger Institut für Sozialforschung 2002) illustrate the circumstances in this camp. These unofficial photographs, termed Knipserfotos (snapshots) in a historic context, were taken by unknown persons, probably by soldiers deployed in the camp, for private purposes. On one picture Soviet POW are depicted, arriving and waiting for registration and disinfection, another picture shows the burrows. Especially the so called Fleischwagen ('meat cart') depicted on the third photograph leaves a disturbing impression. It shows a cart overloaded with dead bodies of Soviet POW, while four men in uniform, probably Soviet POW, on top of the cart, that is on the corpses, are either unloading or loading the cart. Next to the cart stands a young man, Soviet POW (?), thunderstruck staring at several dead bodies on the ground. This photograph is the only one of this shocking and unintentional, even iconic quality. It 'attract(s) strong collective attention and emotional reaction. (..) Unanimity exists (...) that iconic photographs foreground symbolic values' (Ruchatz 2008: 374).

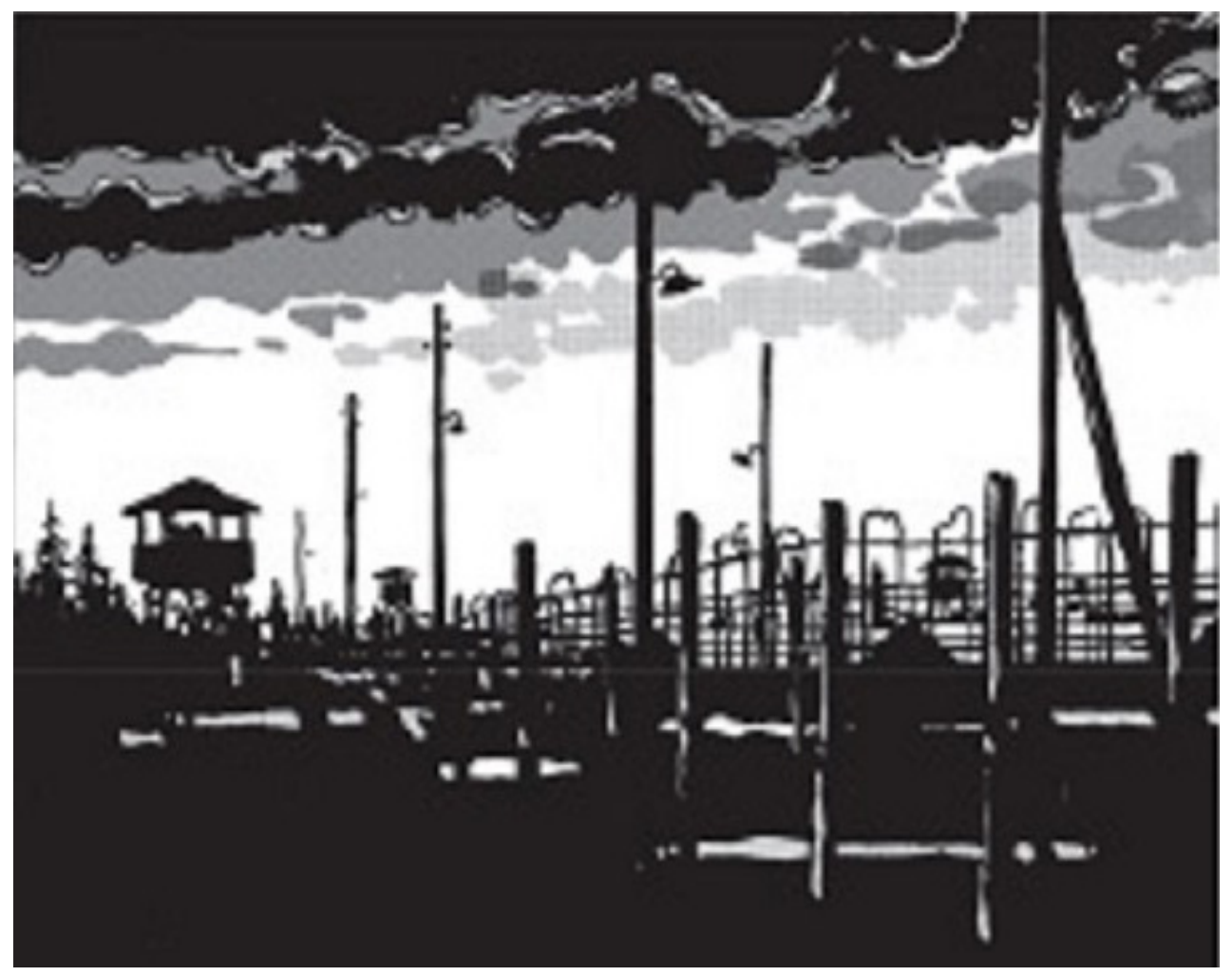

Image 4. StaLag XB Sandbostel, Malet/Tardi, 120 Rue de la Gare, p. 12 (c) 2006 Edition Moderne Zürich

To the historic photographs we juxtaposed pictures from a graphic novel by the French comic artist and son of a former POW Jacques Tardi. This graphic novel from 1988 is a transformation of the plot of the crime novel "120, rue de la Gare" from 1943, whose author Léo Malet, a former French POW in StaLag XB Sandbostel, used motifs describing life in the camp. We juxtaposed the historic photographs documenting the historic moments from the point of view of a military guard taking a snapshot and so giving us an illusion of immediacy, to comic illustrations of a similar setting drawn more than 40 years later by the son of a former French POW. We change the perspective from guards to captives and furthermore, from the agents 
to the descendants. By this artistic transformation we follow the process of transgenerational transmission of traumatic experiences of the POW. On the display we show Tardi's comic version of registration of French POW in StaLag XB Sandbostel. This artistic realization of historic occurrences opens a space for visitors' own imagination and reflection; furthermore it applies especially to a younger public. Next to the cartoon, the imprinted memories of a former Soviet POW describing the situation in the Wietzendorf camp provide visitors with more vivid material for their own contemplation.

\section{Overview of work commandos of Soviet POW in Bremen. Recognition of familiar places}

Soviet POW were only one group among many of forced labourers in the German Reich and, of course, in Bremen. Figures of the Handelskammer (Chamber of Commerce) Bremen show that in 1944 about 54,000 civil labourers from foreign countries, POW and prisoners of concentration camps worked in Bremen at the same time, about 27 per cent of the working population (Pfliegensdörfer 1986: 334). According to our estimates we consider that in 1944 approximately 2,000 Soviet POW were forced to work in Bremen. Several thousands of Soviet POW must have been sent for work to Bremen during the war. Today we know 29 work commandos, some of which were renamed after the administrative restructuring of the military districts.

We indicated the work commandos on a map of the city of Bremen in A0 horizontal format, numbered and provided them with a key on the left side. The work commandos were allocated to various private and public enterprises. To the latter work commandos we assigned the corresponding icons of Wehrmacht, Kriegsmarine, German State Railways and municipality. Present-time photographs showing several places of former work commandos invite visitors to take a different look at their hometown. The recognition of familiar places on the map itself as well as on the accompanying photographs combined with disturbing facts which are not consistent with these places of today is another strategy to arouse visitors' emotions. A feeling of alienation would ensue from this discrepancy, especially taking into consideration that Heimat above all is affirmatively connoted, as shown before. The immanent connection to childhood might have an impact especially on those who grew up in Bremen. 'The past of Heimat as childhood has not passed, is not located beyond presence as a finalized phase. Unlike many memories, Heimat stays present. It protrudes into the respective presence and is involved in its structuring'16 (Hüppauf 2007: 115). Given the factual lack of historic photographs of Soviet POW in Bremen, present-day photographs, localization of work commandos and interviews of contemporary witnesses should serve as adequate triggers for the visitors' imagination.

An important key are traditional companies, such as the brewery Beck's, the automobile and engine works Borgward or the Vulkan dockyard. Though the two latter ones do not exist anymore, they are still identity-establishing in local citizens' perception. Information on this chapter of company history witnessed by genuine Soviet POW is suitable to shake visitors' notions. The depiction of a construction plan titled Russenlager of Vulkan for several barracks built in the middle of a park together with a present-day photo of this place stands for the result of successful protests of influential citizens against the plan to confiscate instead the sports field nearby for this purpose. A protesting letter is depicted as well. Perhaps today in the aftermath, one or another visitor remembers this occurrence in the light of the recent accommodation of refugees in sports halls.

\section{Biographic approach: Andrey Konyukhov, Soviet POW in Bremen, and the contact to his descendants in Russia}

The biographical approach is an especially vivid empathy-evoking device. With the assistance of the German organization Volksbund Deutsche Kriegsgräber-fürsorge (German War Graves Commission) we got into direct contact with the grandniece of a Soviet POW. Andrey Konyukhov had been missed by his family for 70 years, until the organization figured out his fate and informed his relatives that in February 1943 he died in StaLag XB Sandbostel after seven months in a work commando in Bremen. He laboured on the area of a monstrous submarine 
pen, which was never set into operation and has only recently been officially inaugurated as the memorial site "Denkort Bunker Valentin". On the display dedicated to Andrey Konyukhov we show photographs sent by his grandniece. Visitors can see her family in front of her greatuncle's house and family members attending the "Immortal Regiment" on 9 May 2013, the "Day of Victory".

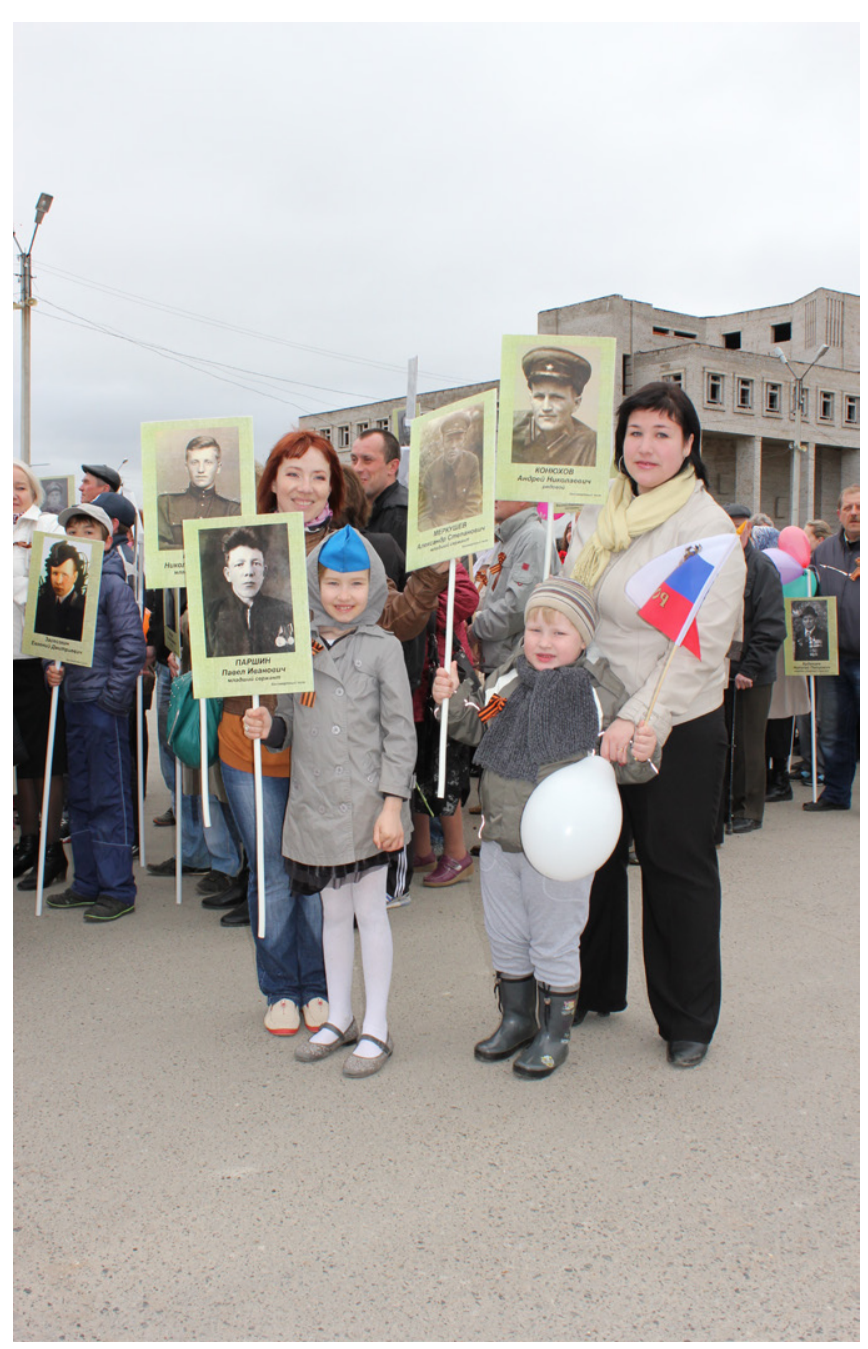

Image 5. Andrey Konyukhov's grandniece with his portrait at the Immortal Regiment, private photograph
On this type of public commemoration in Russia people walk in procession with portraits of their relatives who served in the Red Army during World War II. Started by a citizens' initiative in the Siberian town Tomsk in 2012 and since then horizontally spread over many Russian regions and even cities abroad, in 2015 a parallel allRussian organization close to the government was founded and is heading to exploit this grassroots movement, obviously since it perfectly fits into the official patriotic underpinning of the state policy. One of the initiators gives a sharp witted analysis of this takeover:

What happens today with the 'Immortal Regiment' is the government's attitude towards the people, treating them like a resource. This resource must be managed by someone from above. It cannot be left on its own. Like mineral oil and gas is owned by the government, so are the people, including their memory. I don't like that, because I prefer to dispose of my memory myself ${ }^{17}$.

Thus we can observe the abuse and falsification of authentic feelings for political staging and for the legitimation of an autocratic regime.

The message of Andrey Konyukhov's grandniece to the visitors of the exhibition, which deeply touched us, is depicted in Russian and German. Besides her words of thanks she describes an almost mystical coincidence - the news about her great-uncle's fate, which reached the family during a visit of a member of the Volksbund, and our first mail to her both fell on her grandfather Nicolay's birthday, who had been searching in vain for his brother A. Konyukhov. She writes that she and her family took this coincidence as greetings by their dead relatives. Thus she had transmitted a message from Nicolay and Andrey Konyukhov to us from the beyond - a strong mystical imagination. 


\section{Conclusion}

To give an answer to the question in the introduction - 'How can we examine and present in a historical exhibition a subject - "Russenlager" and forced labour. Soviet prisoners of war in Bremen - that belongs to the dark chapters in the German collective memory, to the longtime denied and covered-up crimes of the Third Reich?': we decided to engage the visitors on different levels. Apart from providing historic information we addressed them emotionally. Starting from local people's affiliation to their geographic surroundings we tried to suggest an altered view on their hometown by showing the hidden and dark sides of 'home'. On a personal level we enabled the visitors to experience a change of perspective by evoking empathy with former Soviet POW and, in one case, with their descendants. Thus, an emotional connection was made across the borders of time and nation. Furthermore, multiple perspectives were provided on an artistic level by using different kinds of presentation from different narrators' points of view, such as present-day and historic photographs, written interviews and graphic illustrations as artistic transformations of historic incidents. By this means, a space could be opened to allow visitors to contemplate.

Received: 1 January 2016 Finally Approved 1 November 2016

\section{References}

Assmann, A. (2003) ,Persönliche Erinnerung und kollektives Gedächtnis in Deutschland nach 1945', in Hans Erler (ed) Erinnern und Verstehen. Der Völkermord an den Juden im politischen Gedächtnis der Deutschen, 126-38, Frankfurt a. M.: Campus.

Assmann, J. (1995) 'Collective Memory and Cultural Identity', New German Critique 65, 12533.

Bausinger, H. (1980) ,Kulturelle Identität - Schlagwort und Wirklichkeit', in Konrad Köstlin and Hermann Bausinger (eds) Heimat und Identität. Probleme regionaler Kultur, 9-24, Neumünster: Wachholtz.

Eigler, F. and Kugele, J. (2012) ,Introduction. Heimat at the Intersection of Memory and Space', in Friederike Eigler and Jens Kugele (eds) Heimat at the Intersection of Memory and Space, 1-14, Berlin, Boston: Walter de Gruyter.

Gebhard, G., Geisler, O, and Schröder, S. (2007) ,Heimatdenken: Konjunkturen und Konturen. Statt einer Einleitung', in Gunther Gebhard, Oliver Geisler and Steffen Schröder (ed) Heimat. Konturen und Konjunkturen eines umstrittenen Konzepts, 9-56, Bielefeld: transcript.

Gedi, N. and Elam, Y. (1996) Collective Memory - What Is It? History and Memory 8 (1) 30-50.

Hamburg Institute of Social Research (ed) (2004) Crimes of the German Wehrmacht: Dimensions of a War of Annihilation 1941-1944. Hamburg: Hamburger Editionhttp://www.verbrechen-der-wehrmacht.de/pdf/vdw_en.pdf.

Hamburger Institut für Sozialforschung (ed) (2002) Verbrechen der Wehrmacht. Dimensionen des Vernichtungskriegs 1941-1944, exhibition catalogue, Hamburg: Hamburger Edition.

(1996) Vernichtungskrieg. Verbrechen der Wehrmacht 1941 bis 1944, exhibition catalogue, Hamburg: Hamburger Edition. 
Heer, H. (2014), Der Skandal als vorlauter Bote. Deutsche Geschichtsdebatten als Generationengespräch', in Jan Lohl and Angela Moré (eds) Unbewusste Erbschaften des Nationalsozialismus. Psychoanalytische, sozialpsychologische und historische Studien, 25-145, Gießen: Psychosozialverlag.

Hense, A. (2008) Verhinderte Entschädigung. Die Entstehung der Stiftung Erinnerung, Verantwortung und Zukunft für die Opfer von NS-Zwangsarbeit und ,Arisierung', Münster: Westfälisches Dampfboot.

Hüppauf, B. (2007) ,Heimat - die Wiederkehr eines verpönten Wortes. Ein Populärmythos im Zeitalter der Globalisierung', in Gunther Gebhard, Oliver Geisler and Steffen Schröder (eds) Heimat. Konturen und Konjunkturen eines umstrittenen Konzepts, 109-40, Bielefeld: transcript.

Pampel, B. (2007) Mit eigenen Augen sehen, wozu der Mensch fähig ist. Zur Wirkung von Gedenkstätten auf ihre Besucher, Frankfurt a. M.: Campus.

Pfliegensdörfer, D. (1986) Vom Handelszentrum zur Rüstungsschmiede. Bremen: Universität Bremen.

Ruchatz, J. (2008) 'The Photograph as Externalization and Trace', in Astrid Erll and Ansgar Nünning (eds) Cultural Memory Studies. An International and Interdisciplinary Handbook, 367-78, Berlin: Walter de Gruyter.

Streit, C. (2012) ,Die sowjetischen Kriegsgefangenen in deutscher Hand - Hunger, Ausbeutung, Massensterben', in Chaja Boebel, Frank Heidenreich and Lothar Wentzel (eds) Vernichtungskrieg im Osten und die sowjetischen Kriegsgefangenen. Verbrechen - Verleugnung - Erinnerung, 60-74, Hamburg: VSA.

Treinen, H. (1988), Was sucht der Besucher im Museum? Massenmediale Aspekte des Museumswesens', in Gottfried Fliedl (ed) Museum als soziales Gedächtnis? Kritische Beiträge zu Museumswissenschaft und Museumspädagogik, 24-41, Klagenfurt: Kärtner Druck- und Verlagsgesellschaft.

Welzer, H., Moller, S. and Tschuggnall, K. (2002) Opa war kein Nazi, Nationalsozialismus und Holocaust im Familiengedächtnis, Frankfurt a. M.: Fischer.

Wickham, Ch. J. (1999) Constructing Heimat in postwar Germany: longing and belonging, New York: The Edwin Mellen Press.

Whitcomb, A. (2013) 'Understanding the role of affect in producing a critical pedagogy for history museums', in Museum Management and Curatorship, 28 (3) 255-71. London: Routledge.

\section{Notes}

1 http://www.verbrechen-der-wehrmacht.de/pdf/vdw en.pdf, accessed 4 November 2015.

2 http://www.stiftung-evz.de/eng/service/dates/opening-of-the-exhibition-forced-labor-thegermans-the-forced-laborers-and-the-war-hamburg.html, accessed 5 November 2015. 
3 http://www.stiftung-evz.de/eng/service/dates/one-time-payment-to-former-soviet-prisonersof-war-in-recognition-of-their-treatment-in-german-detention.html, accessed 14 November 2015.

4 Das Feuer der authentischen Erinnerung wird nach und nach erlöschen. [...] Aufgabe zukünftiger Erinnerungsarbeit wird es sein, die nach dem Ableben der Zeitzeugen nur noch vorhandene mittelbare Erinnerung in vermittelbare Erinnerung zu überführen. [...] Sobald Geschichte an einen Ort gebunden wird, zumal an einen nahe gelegenen, verliert sie die Aura des Abstrakten und rückt uns dagegen im wörtlichen Sinne auf den Leib. Dieser an den eigenen Alltag geknüpften Konfrontation mit Geschichte läßt sich nicht ohne weiteres ausweichen. Korn, S. (2006) ,Gezeitenwechsel', in Frankfurter Allgemeine Zeitung 30 January 2006, p. 8. http://alt.stolpersteine-muenchen.de/Archiv/Presse/060130-faz.htm, accessed 14 November 2015.

5 Ein Rückblick auf das zwanzigste Jahrhundert zeigt, dass ,Heimat' kein harmloses Wort ist. Es gehörte im vergangenen Jahrhundert zu den ideologisch und politisch umkämpften Begriffen und wirkte in Literatur und Politik polarisierend.

6 Heimat als Nahwelt, die verständlich und durchschaubar ist, als Rahmen, in dem sich Verhaltenserwartungen stabilisieren, in dem sinnvolles, abschätzbares Handeln möglich ist - Heimat also als Gegensatz zu Fremdheit und Entfremdung, als Bereich der Aneignung, der aktiven Durchdringung, der Verlässlichkeit.

7 http://gedenkstaettenfoerderung.stiftung-ng.de/de/dokumentationsstelle/dokumentationkriegsgefangenenlager/forschungsprojekt-arbeitseinsatz.html, accessed 4 November 2015.

8 http://obd-memorial.ru/html/index.html, accessed 4 November 2015.

9 http://www.geschichtslehrpfad.de/baracke/baracke.htm, accessed 5 November 2015.

10 http://www.stiftung-lager-sandbostel.del, accessed 4 October 2015.

11 Das abstrakte, auf erlerntem Wissen beruhende Gedächtnis bedarf neuer, sekundärer Formen von Erfahrung und sinnlicher Anschauung, um emotional durchdrungen und persönlich angeeignet zu werden.

12 Bei der persönlichen Wissensvermittlung sind nicht allein Wissensvermittlung oder Gedenken an die Opfer von Bedeutung, sondern die bestätigende Gewissheit durch unmittelbares InAugenschein-Nehmen des historischen Ortes sowie Nachvollzug und Veranschaulichung des Geschehens.

13 Den Besuch als Erlebnis zu organisieren bedeutet, ganzheitliche Erfahrungen mit Herz, Hand und Verstand zu ermöglichen, beispielsweise tieferes Verständnis und plastische Vorstellungsbilder durch Anschaulichkeit, Einfühlung durch biografieorientierte Gestaltung, auratische Erfahrung durch Authentizität (...).

14 Christian Weber, President of the Bremen Parliament, during his opening speech of the exhibition spontaneously mentioned his own memories after having viewed some of the displays in the Haus der Wissenschaft / House of Science in Bremen on 18 September 2014.

15 Gaby Peters, personal communication, 1 November 2015.

Die Vergangenheit der Heimat als Kindheit ist nicht vergangen, liegt nicht als eine abgeschlossene Phase außerhalb der Gegenwart. Heimat bleibt, anders als viele Erinnerungen, Gegenwart. Sie ragt in die jeweilige Gegenwart hinein und ist an deren Strukturierung beteiligt. 
17 То, что происходит сегодня с «Бессмертным полком» это отношение государства к людям, как к ресурсу. Этот ресурс должен управляться кем-то сверху. Он не может быть сам по себе. Вот как нефть, газ принадлежат государству, так точно и люди, их память в том числе. Мне это не нравится, потому что я своей памятью предпочитаю распоряжаться сам. http://ndn.info/mneniya/5824-zachem-ponadobilsya-eshche-odinbessmertnyj-polk, accessed 11 November 2015.

Kerstin True-Biletski and Petra Redert attained their Master's degrees in East and East Central European cultural history at the University of Bremen in 2009 and 2012.

*Kerstin True-Biletski's master's thesis deals with spatial and temporal structures in Ivan Bunin's prose. Her second subject was German Studies. She translated from Russian to German as a freelancer, from 2010 until 2012 she managed the DAAD-funded project 'StudentService@ School'. She works as an administration assistant and is Erasmus Coordinator at the Faculty of Law, University of Bremen.

**Petra Redert's master's thesis analyzes the key function of Tarot in Pushkin's novella 'Queen of Spades'. Her subsidiary subjects were Labour Studies and Polish Studies. She is a selfemployed master bricklayer and member of the German-Belarussian charitable association ÖkoBau (Minsk, Belarus), which helps to overcome the impacts of the Chernobyl reactor catastrophe by building ecological houses, community facilities and renewable-energy power plants in Belarus.

Petra Redert

Beginenhof 4

D-28201 Bremen

Germany

petraredert@gmx.de

Tel./Fax: +49 (0)421 2760221

Kerstin True-Biletski

Universität Bremen

Fachbereich Rechtswissenschaft

Universitätsallee GW 1

D-28359 Bremen

Germany

ktrue@uni-bremen.de

Tel.: +49 (0)421 218-66044

Fax: +49 (0)421 218-66052 